\title{
Glucose restriction decreases telomerase activity and enhances its inhibitor response on breast cancer cells: possible extra-telomerase role of BIBR 1532
}

\author{
Layal Wardi ${ }^{1}$, Nada Alaaeddine ${ }^{2}$, Issam Raad ${ }^{3}$, Riad Sarkis ${ }^{4}$, Rim Serhal ${ }^{2}$, Charbel Khalil ${ }^{2}$ and George Hilal ${ }^{1 *}$
}

\begin{abstract}
Background: Considerable progress has been made to understand the association between lifestyle and diet in cancer initiation and promotion. Because excessive glucose consumption is a key metabolic hallmark of cancer cells, glucose restriction (GR) decreases the proliferation, and promotes the differentiation and transformation of cancer cells to quiescent cells. The immortality of cancerous cells is largely assured by telomerase, which is an interesting target for inhibition by BIBR 1532. In this study, we investigated the effect of GR on telomerase activity and on the efficacy of its inhibition by BIBR 1532.
\end{abstract}

Methods: Breast cancer MDA-MB 231 and MCF-7 cells were cultured in DMEM (Dulbecco's modified eagle's media) with 0,1 or $4.5 \mathrm{~g} /$ l of glucose. The telomerase activity was measured via quantitative Real-Time PCR, and the two telomerase subunits were semi-quantified by RT-PCR. Proliferation test and mitochondrial metabolism were assessed via tetrazolium salt reduction and cell counts; apoptosis was assessed via caspase-3 quantification and flow cytometry.

Results: A decrease in the telomerase activity of more than $75 \%$ was associated with a significant reduction in the mRNA expression of its catalytic subunit hTERT (Reverse Transcriptase) and a decrease in the mitochondrial metabolism by more than $80 \%$ under restricted glucose conditions. In addition, GR increased the effect of BIBR 1532. Glucose deprivation induces apoptosis via BIBR 1532-mediated telomerase inhibition in triple negative breast cancer cells, as assessed by caspase-3 measurements and Annexin analysis.

Conclusions: Taken together, our results suggest that the effect of BIBR 1532 is potentiated by GR to induce triple negative breast cancer cell death.

Keywords: Glucose restriction, Cancer, Telomerase, Breast cancer, BIBR 1532

\section{Background}

Caloric restriction $(\mathrm{CR})$ or reducing the total caloric intake by 20 to $40 \%$ without limiting essential vitamins and minerals has long been considered as a means to prevent and cure cancer and to extend life span [1-3]. Recently, a potential role of $\mathrm{CR}$ in the treatment and intervention of agerelated diseases, including cardiovascular disease, diabetes,

\footnotetext{
* Correspondence: george.hilal@usj.edu.lb

${ }^{1}$ Cancer and Metabolism Laboratory, Faculty of Medicine, Campus of Medical Sciences, Saint-Joseph University, Damascus Road, P.O.Box 11-5076, Riad el Solh, Beirut 1107 2180, Lebanon

Full list of author information is available at the end of the article
}

hypertension, atherosclerosis and cancer, has been investigated $[4,5]$.

Cancer is a complex disease associated with multiple DNA mutations that lead to abnormal cell proliferation, immortality and tissue invasion at distant sites [6]. The strong relationship between nutrition and cancer, as also demonstrated by several epidemiological studies $[7,8]$, has been extrapolated by some clinicians into complete abstinence from food. In fact, ten oncologists did allow their patients who suffered from breast, esophageal, prostate and lung cancer to fast from 48 to 140 hours prechemotherapy and 5 to 56 hours post chemotherapy [9].

\section{Biomed Central}

(c) 2014 Wardi et al.; licensee BioMed Central Ltd. This is an Open Access article distributed under the terms of the Creative Commons Attribution License (http://creativecommons.org/licenses/by/2.0), which permits unrestricted use, distribution, and reproduction in any medium, provided the original work is properly credited. The Creative Commons Public Domain Dedication waiver (http://creativecommons.org/publicdomain/zero/1.0/) applies to the data made available in this article, unless otherwise stated. 
Patients who received chemotherapy with water-only fasting reported a reduction in side effects and also showed a better response to treatment than the control group. This latter observation contradicts the dietary recommendation of the American Cancer Society that advises patients to increase their protein and calorie intake before chemotherapy administration.

Cell division is potentially a risky process, and cell division is limited in normal tissues. Telomerase is upregulated in $85 \%$ of malignant tumors. Therefore, they escape senescence to have unlimited cell division at the earlier stage of tumorogenesis [10]. Telomerase is the key enzyme responsible for the immortalization of cancerous cells [11].

Telomerase is a ribonucleoprotein complex enzyme that consists of two major subunits, the human Telomerase Reverse Transcriptase (hTERT) and human RNA component (hTR), in addition to several accessory proteins that modulate the activity of this enzyme [12]. Eighty five percent of malignant tumors escape senescence to have unlimited cell division following telomerase up-regulation during the early stages of tumorogenesis [10]. The enzyme telomerase stabilizes the length of telomeres, the end of linear chromosomes, via the de novo addition of telomeric repeats, which have been lost during incomplete DNA replication, telomere degradation or oxidative stress. The telomerase-induced telomere maintenance and reparation is believed to play a critical role in senescence, aging and cancer [13]. Human telomerase consists of two major subunits, the human Telomerase Reverse Transcriptase (hTERT) and human RNA component (hTR), in addition to several accessory proteins that modulate the activity of this enzyme [12].

An increasing body of literature has demonstrated that several metabolic changes occur during cancer evolution [14]. On the molecular level, cancer cell proliferation is tightly related to cell metabolism [15]. In multicellular organisms, cell proliferation is controlled, and any aberrant individual cell proliferation is prevented when nutrients exceed the levels needed to support cell division. In contrast, cancer cells overcome this growth factor control via several DNA mutations that alter the receptorinitiated signaling pathway [16,17]. This altered metabolism of tumor cells is exhibited by an increased glucose uptake and elevated aerobic glycolysis, which was first recognized by Warburg 70 years ago [18]. Unsurprisingly, abnormal glucose metabolism has become the target of several studies because of its uniqueness in cancer cells and its possible role in preventing and curing cancer. However, GR is a metabolic stressor to many signaling pathways, including the anti-apoptotic pathway IGF1R-IR/ PI3K/Akt/mTOR [19]. Glycolytic enzymes are up-regulated following the activation of this pathway. In addition to glycolysis activation, c-Myc and SP1, which are transcription factors induced by a high glucose level, cooperate to activate the transcription of the catalytic subunit of telomerase (hTERT) [20] The activation of AMP-activated protein kinase by GR down-regulates mTOR, glycolysis activity, and cell proliferation [21-23]. Furthermore, glucose withdrawal increases ketone bodies in the blood circulation. These ketone bodies can reportedly help to prevent and treat cancer by protecting mitochondria from inflammation and ROS (Reactive Oxygen Species) [24]. Finally, Li and colleagues [25] demonstrated that GR impairs precancerous cell growth via the epigenetic control of the telomerase subunit (hTERT) and p16 expression.

GR is an attractive modality to explore because it has been shown to induce changes in molecular pathways, especially those altered in cancer. Altering these pathways could make cells more susceptible to treatment with the telomerase inhibitor BIBR 1532. This drug is a potent and selective inhibitor of two telomerase units; it interferes with the action of telomerase [26].

The primary objective of this article was to investigate the effect of GR on the telomerase activity and on its inhibition by BIBR1532 in two breast cancer cell lines, the highly invasive and metastatic triple-negative (ER-, PR-, Her2-) MDA-MB 231 and the less invasive Estrogendependent $(\mathrm{ER}+) \mathrm{MCF}-7$ cells.

\section{Results}

\section{Effect of glucose restriction (GR) on telomerase activity}

The effect of GR on the telomerase activity was first assessed using the MDA-MB 231 and MCF-7 breast cancer cell lines. Figure 1 shows that decreasing the glucose concentration in culture media led to a partial telomerase activity inhibition at 1 and $0 \mathrm{~g} / \mathrm{l}$. Importantly, the cells incubated with $0 \mathrm{~g} / \mathrm{l}$ of glucose were cultured in $10 \%$ of FBS that contains $0.65 \mathrm{~g} / \mathrm{l}$ of glucose. This concentration was measured for each test in a medical laboratory and mimics physiological glycaemia in fasting situations. MDA-MB 231 reduced their telomerase activity in response to GR by more than $50 \%(\mathrm{P}<0.05)$ and $80 \%(\mathrm{P}<0.01)$ at $1 \mathrm{~g} / \mathrm{l}$ and $0 \mathrm{~g} / \mathrm{l}$ of glucose, respectively. This same pattern was evident in MCF-7 cells, as indicated in Figure 1b. The telomerase activity decreased by $40 \%$ and $75 \%$ in cells incubated in DMEM containing $1 \mathrm{~g} / \mathrm{l}(\mathrm{P}<0.05)$ and $0 \mathrm{~g} / \mathrm{l}$ glucose $(\mathrm{P}<0.01)$, respectively.

\section{Glucose restriction but not BIBR 1532 impaired hTERT expression}

Because the hTR component is constitutively expressed in all cells and hTERT is up-regulated in most tumor cells, we investigated the ability of GR to modulate the expression of hTERT in human breast cancer cell lines after $48 \mathrm{~h}$ of treatment with $10 \mu \mathrm{M}$ BIBR1532. The RTPCR method was used to examine the expression of both hTR and hTERT mRNA using GAPDH as an internal 


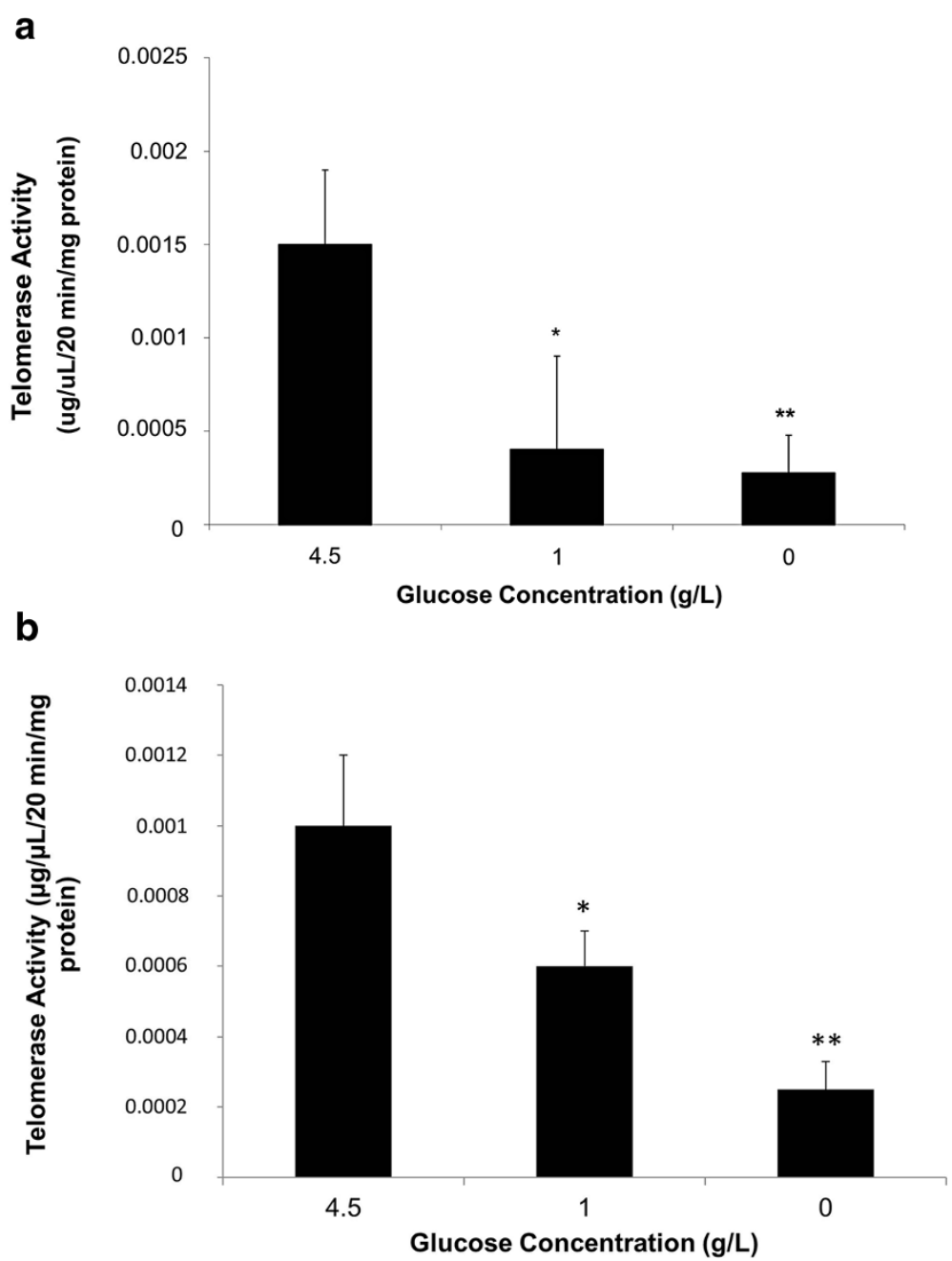

Figure 1 Effect of GR on the telomerase activity. a. MDA-MB 231 and b. MCF-7 cells were seeded in $75 \mathrm{~cm}^{2}$ flasks and grown in DMEM culture medium containing 10\% FBS and 1\% Pen/Strep at different glucose concentrations (0, 1 and $4.5 \mathrm{~g} / \mathrm{L}$ of glucose). After 5 days of pre-incubation in the appropriate medium 1.5 million cells of each condition were prepared for the telomerase activity and protein measurements. The bars represent values from at least three independent experiments $\left({ }^{*} \mathrm{P}<0.05\right.$, $\left.{ }^{* *} \mathrm{P}<0.01\right)$.

control. Importantly, BIBR 1532 inhibits the protein, but not the mRNA level of hTERT; it inhibits the mechanism of action of the enzyme.

The relatively high telomerase activity at high glucose concentrations shown in Figure 1 was confirmed by high mRNA expression (Figure 2). However, we could not demonstrate any changes in the expression of hTERT and hTR mRNA in cells grown in 1 and $0 \mathrm{~g} / \mathrm{l}$ of glucose; hTERT was expressed at 55\% $(\mathrm{P}=0.0248)$ and $59 \%$ $(\mathrm{P}=0.033)$ at 1 and $0 \mathrm{~g} / \mathrm{l}$ of glucose, respectively, in MDAMB 231, while hTERT was expressed at $41 \%(\mathrm{P}=0.021)$ and $37 \%(\mathrm{P}=0.0178)$ in $0 \mathrm{~g} / \mathrm{L}$ and $1 \mathrm{~g} / \mathrm{L}$, respectively, in MCF-7 cells, as shown in Figure 2c. As expected, BIBR 1532 did not affect the telomerase transcription because it acts directly on the protein.

\section{Glucose restriction decreased cell proliferation and} enhanced the effect mediated by BIBR 1532

The effect of GR on the MDA-MB 231 cell count and proliferation was only significant at $0 \mathrm{~g} / \mathrm{l}$ of glucose compared to $4.5 \mathrm{~g} / \mathrm{l}$ of glucose, as shown in Figure 3a. Although cell proliferation at $1 \mathrm{~g} / \mathrm{l}$ of glucose seems to be lower compared to cells grown in $4.5 \mathrm{~g} / \mathrm{l}$ of glucose, the results did not reach significance $(\mathrm{P}=0.08)$. In contrast, the proliferation of cells in $0 \mathrm{~g} / \mathrm{l}$ of glucose was very slow, and this difference was statistically very significant compared to those incubated in 1 and $4.5 \mathrm{~g} / \mathrm{l}$ of glucose $(\mathrm{P}<0.001)$. The effect of the telomerase inhibitor BIBR 1532 was very pronounced for cells grown in $0 \mathrm{~g} / \mathrm{l}$ of glucose. By the end of week three, the number of cells incubated in $0 \mathrm{~g} / \mathrm{l}$ of glucose and $2.5 \mu \mathrm{M}$ BIBR 1532 was 


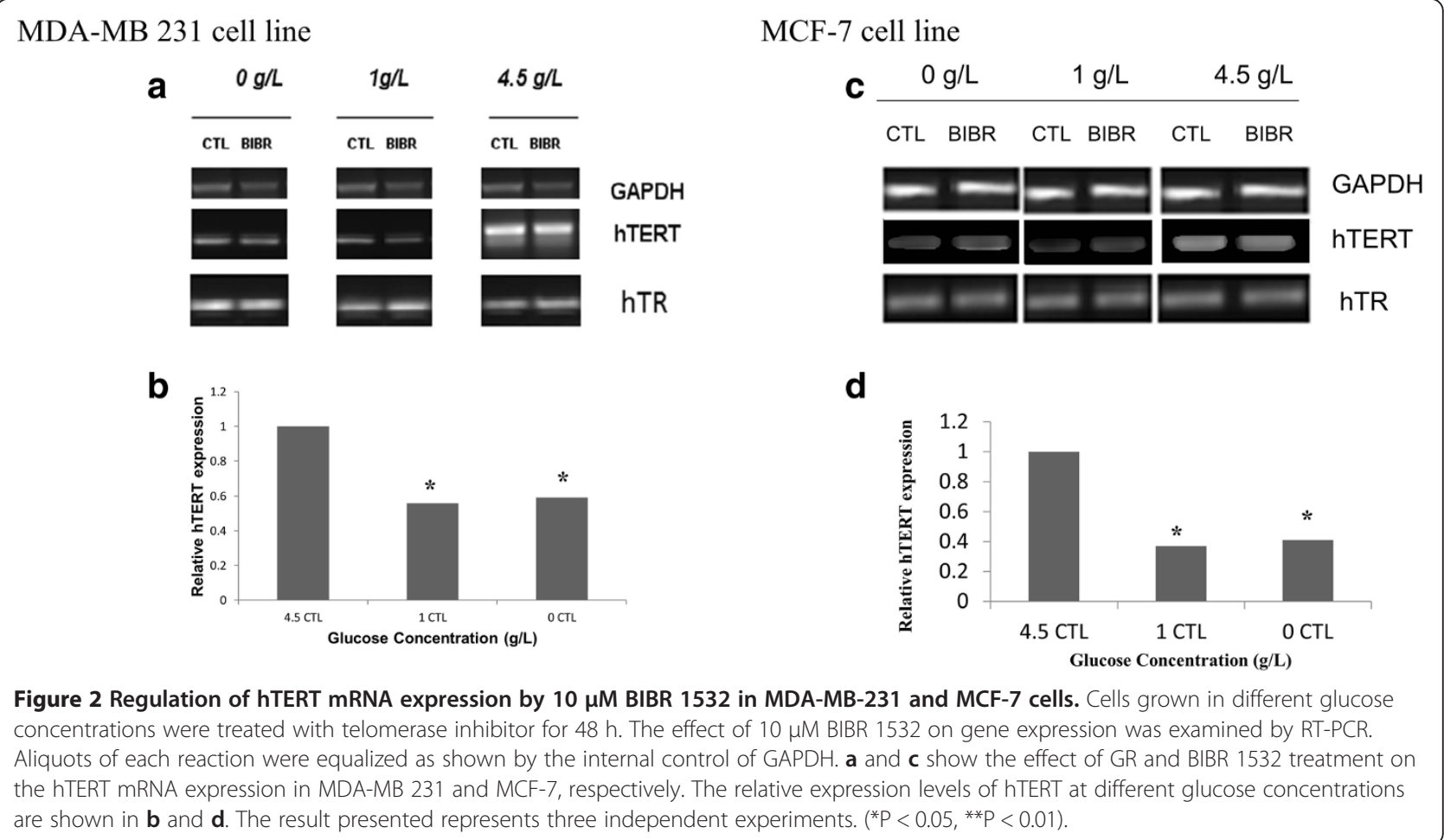

almost zero (Figure 3a). Contrary to this result, BIBR 1532 seemed to have an effect in weeks one and two for cells grown in 1 and $4.5 \mathrm{~g} / \mathrm{l}$ of glucose. This trend disappeared at week three, and the level of cell proliferation was similar to that of the control.

The effect of GR was more pronounced on the MCF-7 cell line. As shown in Figure $3 b$, reducing the glucose concentration in the media significantly decreased the cell proliferation over time. The proliferation of cells grown without glucose reduced by $30 \%$ from the first week $(P=0.057)$, and this reduction was enhanced at the second week, when only less than $40 \%$ of cells remained alive $(\mathrm{P}=0.0001)$. The MCF-7 cell count was not extended into the third week because all of the cells grown in DMEM containing $0 \mathrm{~g} / \mathrm{L}$ of glucose had died. Cells incubated in $1 \mathrm{~g} / \mathrm{L}$ of glucose exhibited reduced proliferation by $20 \%$ at the second week $(P=0.0139)$. After 15 days, $2.5 \mu \mathrm{M}$ BIBR 1532 could reduce cell proliferation by $35 \%$ only when cells were incubated in physiological glucose concentrations $(\mathrm{P}=0.0051)$.

\section{Regulation of mitochondrial metabolism by glucose restriction and BIBR 1532}

Water-soluble tetrazolium salt WST-1 was used to assess the cell viability. This test reflects not only the cell viability but also the metabolism of mitochondria, as reported by several works $[27,28]$. Figure 4 a shows that GR apparently decreased the succinate reductase activity in MDA-MB 231 cells by $55 \%$ and by more than 5 -fold for cells grown in $1 \mathrm{~g} / \mathrm{l}$ and $0 \mathrm{~g} / \mathrm{l}$ of glucose, respectively. In MCF-7 cells, GR reduced the mitochondrial activity by $35 \%$ and by more than $80 \%$ in cells grown in $1 \mathrm{~g} / \mathrm{l}$ and $0 /$ gl glucose, respectively $(P=0.0009)$. This decrease was not caused by cell death because healthy quasiconfluent cells were detected in all wells using microscopic examination, bromophenol blue staining, and cell counts. This experiment was extended to evaluate the effect of BIBR 1532 in the GR conditions. As shown in Figure 5a, BIBR 1532 significantly reduced succinate reductase activity in MDA-MB 231 cells grown in $1 \mathrm{~g} / \mathrm{L}$ and $4.5 \mathrm{~g} / \mathrm{L}$ glucose. This effect was potentiated at a high glucose level $(4.5 \mathrm{~g} / \mathrm{L})$, where $10 \mu \mathrm{M}$ BIBR 1532 could reduce WST-1 transformation by $35 \%$. However, this effect was absent when cells were grown in $0 \mathrm{~g} / \mathrm{l}$ glucose.

As shown in Figure 5b, higher concentrations of BIBR 1532 are required to elicit the same effect observed in MDA-MB 231 cells. This telomerase inhibitor could reduce WST-1 transformation by $25 \%$ starting from $50 \mu \mathrm{M}$, and this reduction became more significant when the BIBR 1532 concentration was increased to $100 \mu \mathrm{M}$ $(\mathrm{P}=0.0011)$. A high concentration of BIBR $1532(100 \mu \mathrm{M})$ is required to inhibit the mitochondrial metabolism by $\sim 25 \%$ in cells incubated in $1 \mathrm{~g} / \mathrm{L}$ of glucose $(\mathrm{P}=0.029)$. This modulator effect was absent in cells grown without glucose.

Telomerase-negative human osteosarcoma Saos-2 cells have previously been studied to examine the role of telomerase in mitochondrial metabolism modulation. The 


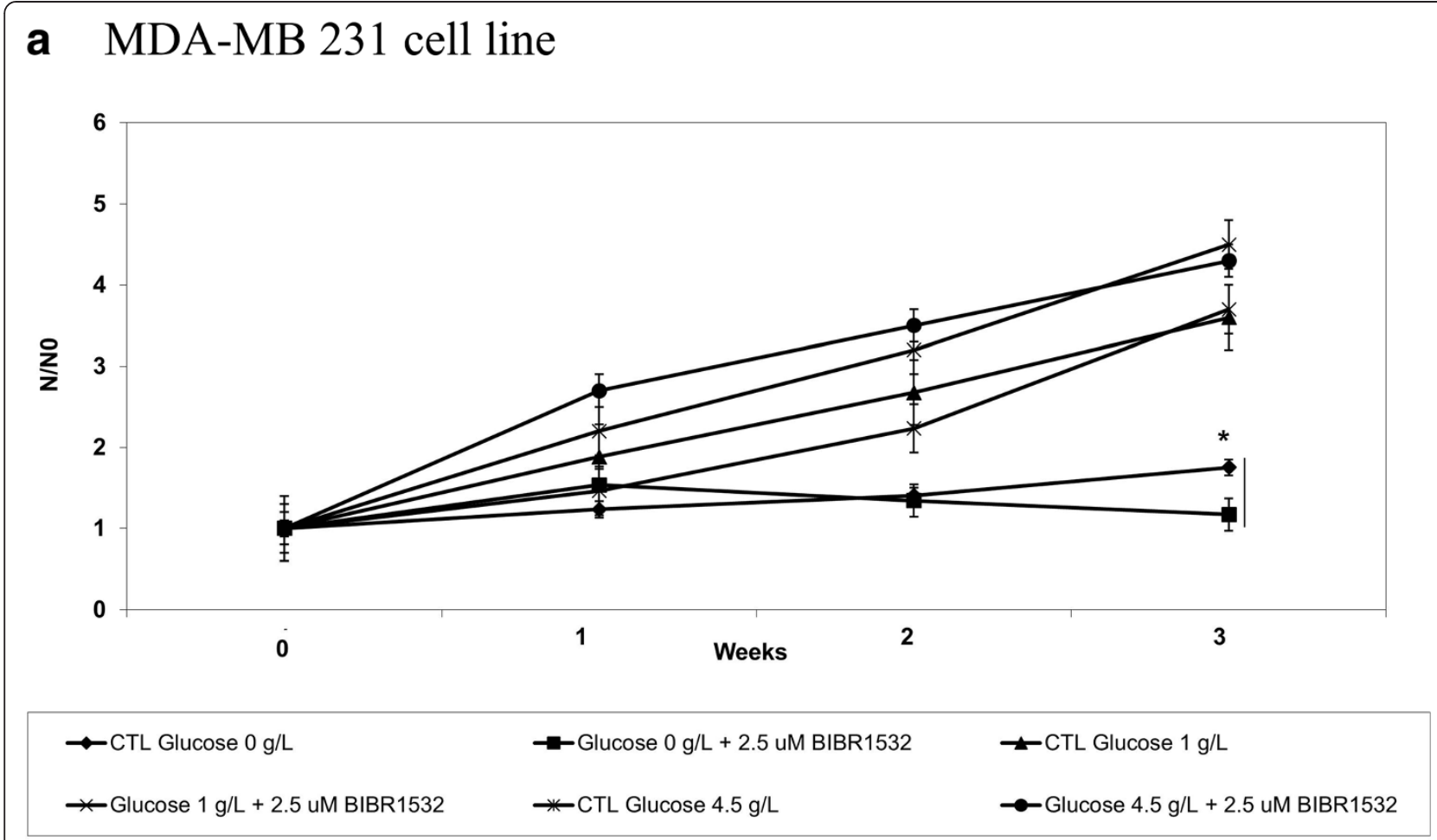

\section{b $\mathrm{MCF}-7$ cell line}

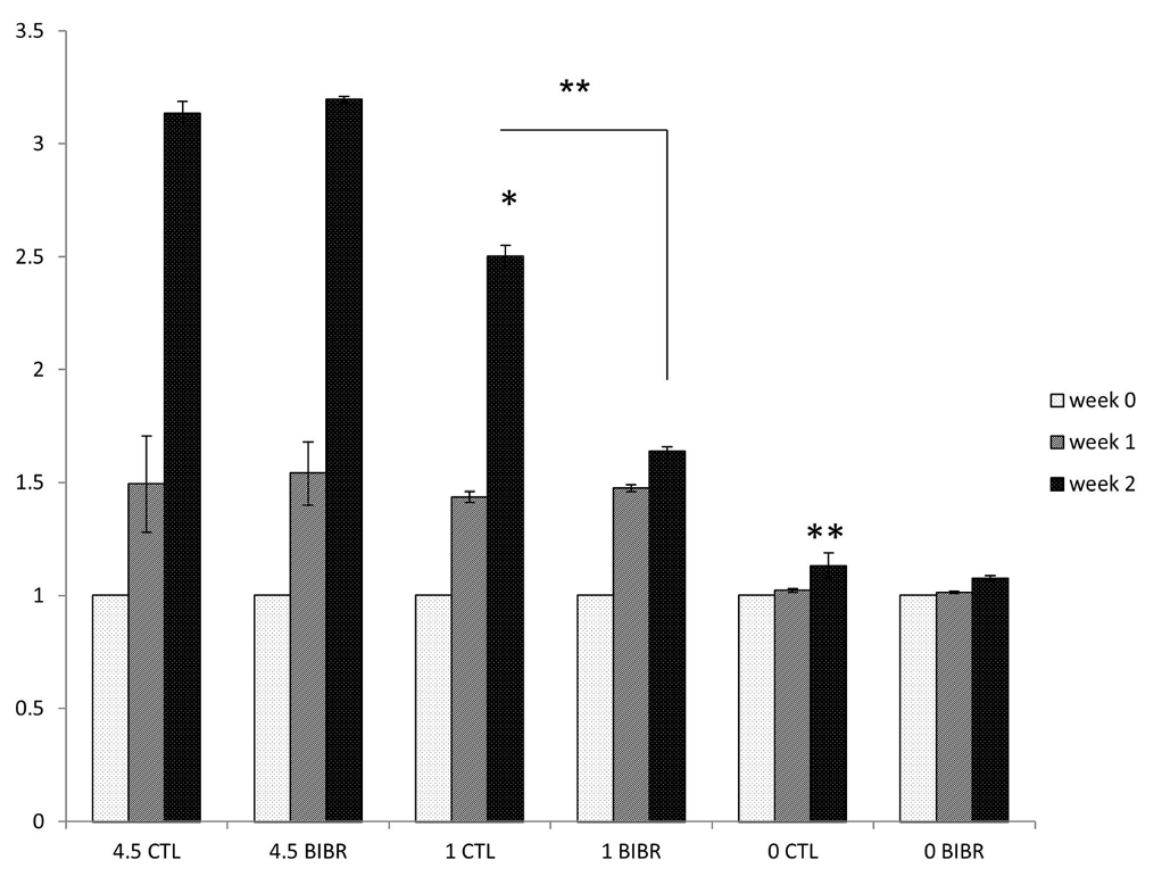

Figure 3 (See legend on next page.) 
(See figure on previous page.)

Figure 3 Effect of GR on the proliferation of MDA-MB 231 and MCF-7 BIBR 1532 treated cells. The cells were seeded at a very low density in a $25 \mathrm{~cm}^{2}$ flask and grown in DMEM culture medium containing 10\% FBS and 1\% Pen/Strep at different glucose concentrations with or without $2.5 \mu \mathrm{M}$ of BIBR 1532. The medium was replaced every two days, and fresh telomerase inhibitor was added each time. At the end of each week, the cells were split and counted at least three times using bromophenol blue and a hemocytometer. $\mathbf{a}$ and $\mathbf{b}$ show the effect of GR and treatment with $2.5 \mu \mathrm{M}$ BIBR 1532 on MDA-MB 231 and MCF-7 cells based on the obtained cell number after each count compared to the number seeded cells. Bars represent values from at least three independent experiments $\left({ }^{*} p<0.05,{ }^{*} p<0.01\right)$.

Saos2 cell line was cultured in different glucose concentrations and then treated with 10 and $50 \mu \mathrm{M}$ BIBR 1532 over $48 \mathrm{~h}$. The results demonstrated that GR displayed the same profile as those exhibited by the two breast cancer cell lines. Reducing the glucose concentration in the media decreases the WST-1 transformation by $40 \%$ and more than $80 \%$ for cells grown in $1 \mathrm{~g} / \mathrm{L}$ and $0 \mathrm{~g} / \mathrm{L}$ glucose, respectively (Figure 5c). As shown in Figure 5d, BIBR 1532 exhibits the same effect in Saos-2 cells grown in 1 and $4.5 \mathrm{~g} / \mathrm{L}$ glucose $(\mathrm{P}=0.017$ and $\mathrm{P}=0.0032$, respectively).

\section{hTERT mRNA silencing did not affect mitochondrial metabolism}

To further validate the results concerning the modulation of mitochondrial metabolism by BIBR 1532, we treated MDA-MB 231 and MCF-7 cells grown at different glucose concentrations with TERT siRNA. Surprisingly, Figure $6(\mathrm{a}, \mathrm{b})$ shows that $20 \mathrm{nM}$ TERT siRNA did not affect the formazan dye formation compared to the control at the three different glucose concentrations; however, a decreased tendency was evident only in cells incubated in $4.5 \mathrm{~g} / \mathrm{l}$ glucose. The transfection efficiency was confirmed by using electrophoresis and cell death control, which is a blend of highly potent siRNAs targeting ubiquitously expressed human genes indispensable for cell survival (Figure 6) and hTERT gene expression. This apparently discrepant result could be explained by a high residual telomerase activity even after partial hTERT mRAN silencing. Furthermore, hTERT siRNA likely did not elicit an effect similar to that of BIBR 1532 due to the insufficient incubation time to deplete hTERT.

\section{Glucose deprivation induced apoptosis mediated by BIBR 1532}

To demonstrate whether BIBR 1532 induced apoptosis in MDA-MB 231 and MCF-7 cells, the expression of caspase-3 was assessed via ELISA (Invitrogen).

Although apoptotic signals are believed to be mediated by a hierarchy of caspase activation, only two pathways of caspase activation have been described. Nevertheless, caspase-3 is a common downstream enzyme activated in apoptosis that is induced by most stimuli.

The level of caspase- 3 was measured in cells grown at different concentrations of glucose in the presence and absence of a high concentration of BIBR $1532(50 \mu \mathrm{M})$.

\section{MDA-MD 231 cell line}

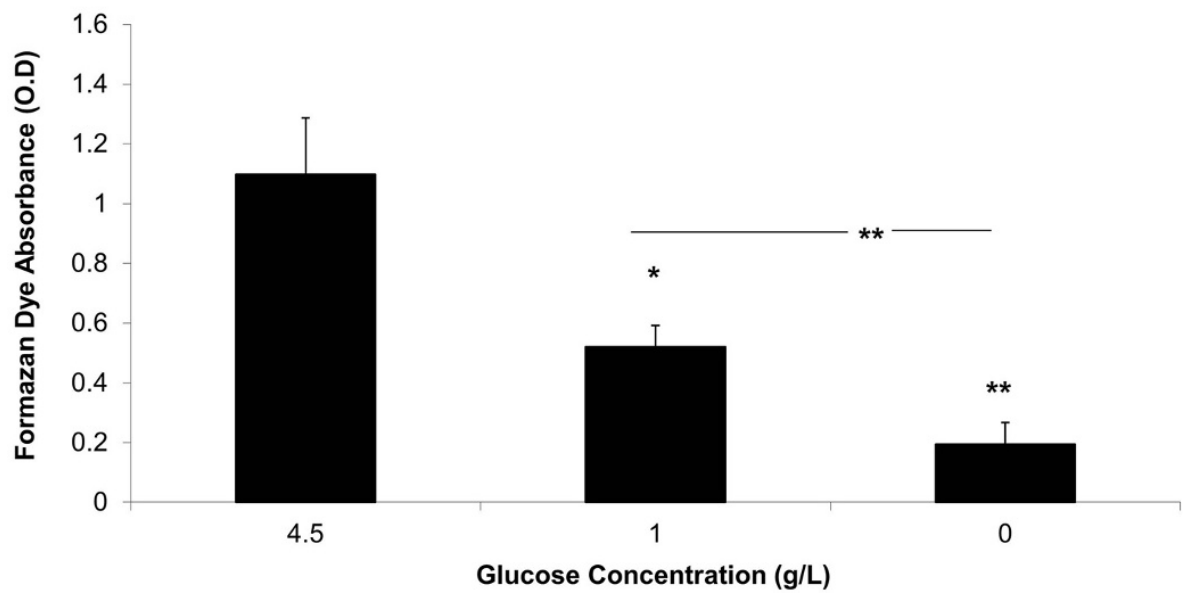

Figure 4 Effect of GR on cell viability and mitochondrial metabolism. The MDA-MB 231 cells grown in DMEM with different glucose concentration were equally seeded in 96-well plates at a density of $10^{4}$ cells/well. Twenty-four hours later, cells received $10 \mu$ l of tetrazolium salt and were incubated for 60 minutes at $37^{\circ} \mathrm{C}$. The formation of formazan dye was assessed using an ELISA reader at $450 \mathrm{~nm}$. The O.D. of each condition is a mean of 12 wells. Bars represent values from at least three independent experiments. $\left({ }^{*} p<0.05\right.$ and $\left.{ }^{* *} p<0.01\right)$. 


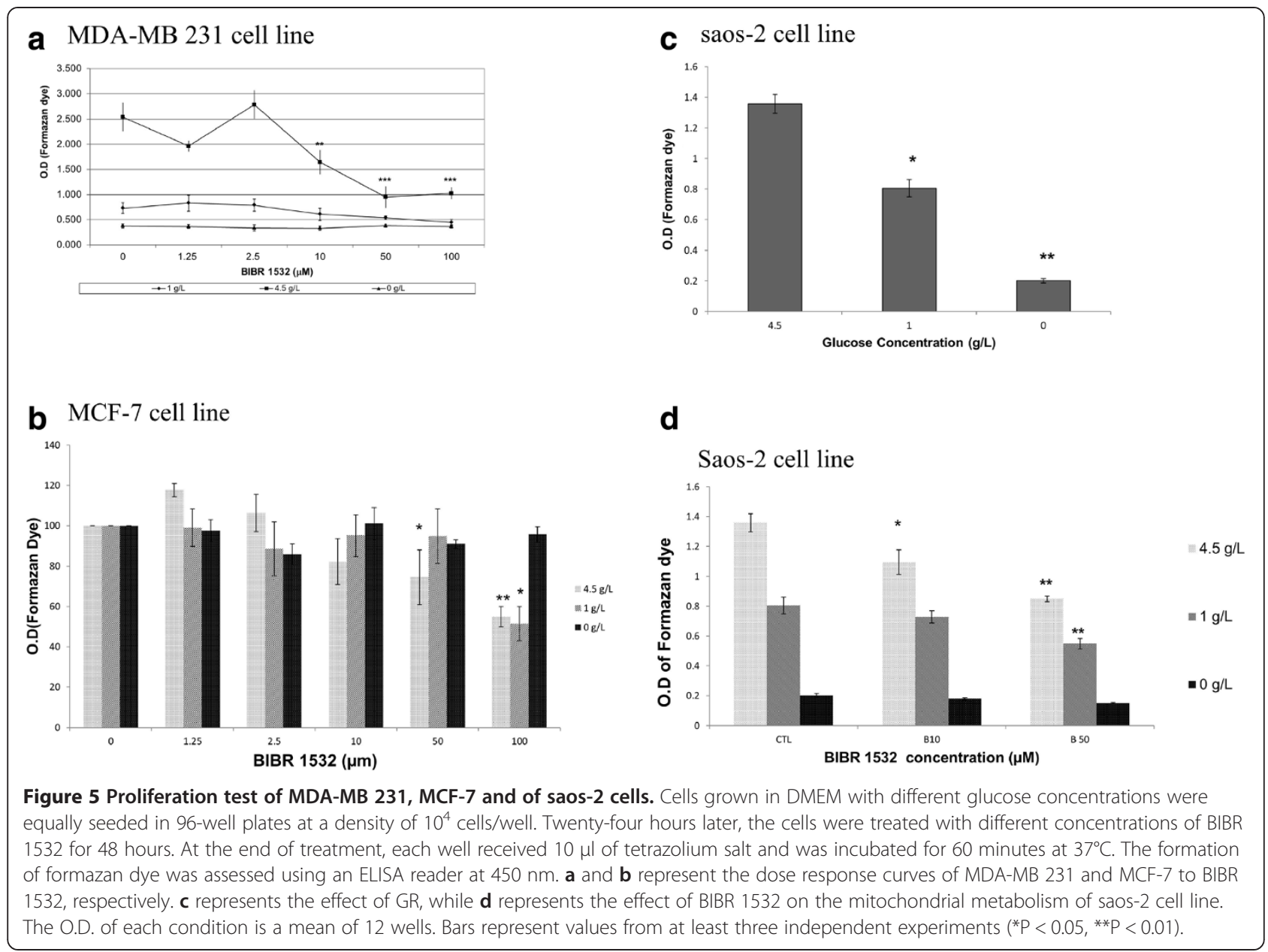

Figure 7 demonstrates that $50 \mu \mathrm{M}$ BIBR 1532 did not affect MDA-MB 231 apoptosis except in cells grown in $0 \mathrm{~g} / \mathrm{l}$ of glucose. Caspase- 3 was not expressed in MCF-7 cells, and this result confirmed several reports that indicated caspase-3 deficiency in this cell line.

Caspase-3 expression was not detected in the Saos-2 cell line incubated at different glucose concentrations or treated with BIBR 1532. (Data not shown).

The results obtained from this experiment suggest that caspase-3 is involved in the induction of apoptosis in BIBR 1532-treated MDA-MB 231 cells that are deprived of glucose. Apoptosis induction was also investigated via annexin $\mathrm{V}$ staining. Figure 8 and Tables 1 and 2 shows same results displayed in Figure 7. The percentage of annexin V-positive cells significantly increased in treated cells with BIBR 1532 without glucose compared to the control cells. These data suggest that the growth inhibitory effect of BIBR 1532 on MDA-MB 231 cells is partly due to its effect on apoptosis induction under restricted glucose conditions. In the MCF-7 cell line, high concentrations of BIBR 1532 did not elicit apoptosis as observed in MDA-MB 231, unless cells incubated in high glucose concentration $(4.5 \mathrm{~g} / \mathrm{L})$ are treated with $50 \mu \mathrm{M}$ BIBR 1532, as shown in Figure 8b and Tables 1 and 2.

\section{Discussion}

Due to its major role in cell immortalization, telomerase has become an attractive target for selective cancer therapy. Several approaches have been studied to decrease or completely inhibit the activity of telomerase. Among these efforts, we mention the direct and indirect inhibition of telomerase, immunotherapy using hTERT as a tumorassociated antigen, and gene therapy with a promoterdriven suicide promoter [27]. Because its expression is mainly restricted to tumor cells and it is the rate-limiting subunit in telomerase activity, hTERT has become the main target of inhibition to stop tumor growth. However, these efforts directly face a major obstacle described by the lag phase between the initiation of telomerase inhibition and the impact on the proliferation capacity $[29,30]$. Therefore, tumor cells with long telomeres will continue to grow upon telomerase inhibition until substantial telomere erosion has occurred. This limitation negatively impacts the application of this inhibition in patients with a 


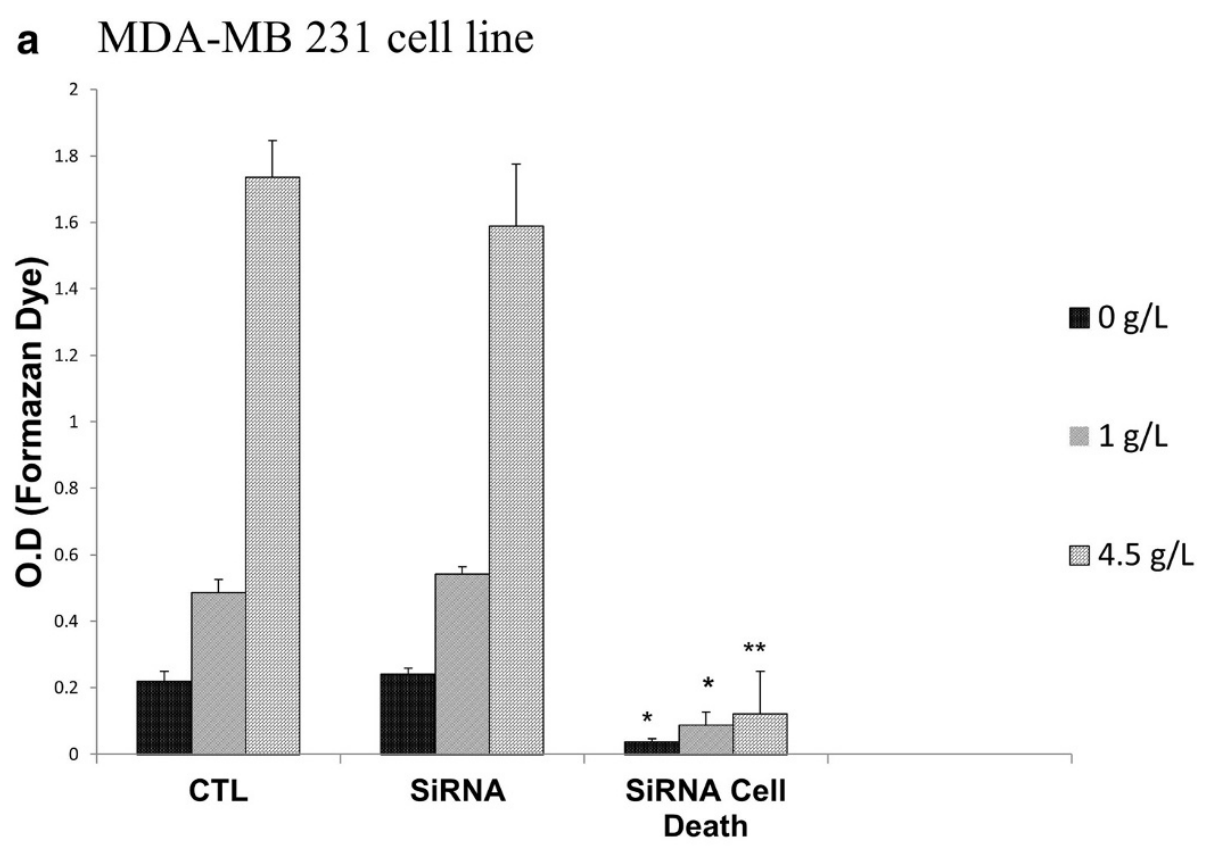

\section{b $\mathrm{MCF}-7$ cell line}

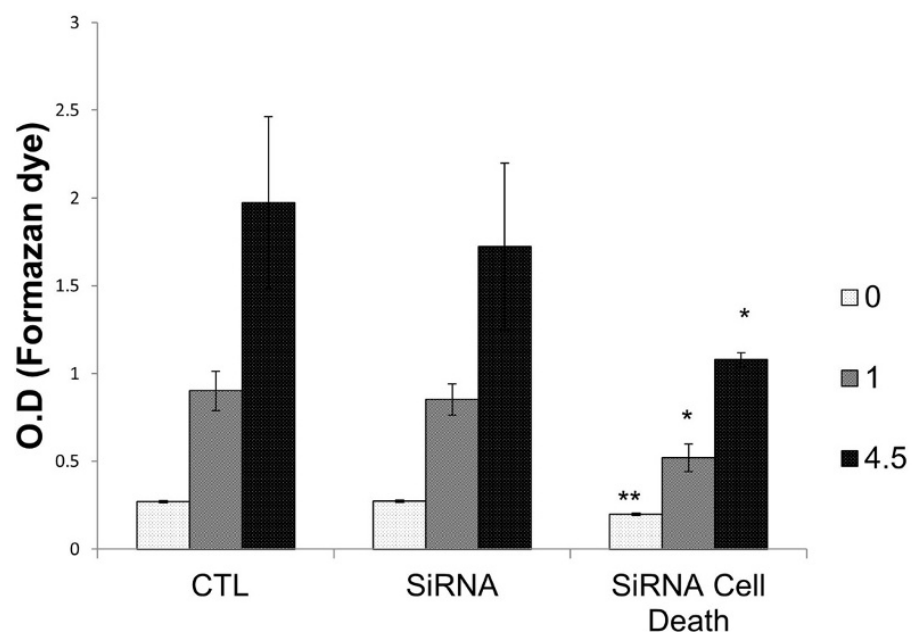

Figure 6 Effect of telomerase siRNA on cell viability and mitochondrial metabolism. MDA-MB 231 (a) and MCF-7 (b) cells grown in DMEM with different glucose concentrations were equally seeded at a density of $2 \times 104$ in a 96-well plate 10 min after $20 \mathrm{nM}$ SiRNA transfection. Seventy-two hours later, each well received $10 \mu \mathrm{l}$ of WST-1 and was incubated for 60 minutes at $37^{\circ} \mathrm{C}$. The formation of formazan dye was assessed using an ELISA reader at $450 \mathrm{~nm}$. The O.D. of each condition is a mean of 12 well. Bars represent values from at least three independent experiments. $\left({ }^{*} P<0.05\right.$, $\left.{ }^{* *} P<0.01\right)$.

high tumor mass. Out of several telomerase inhibitors, two molecules have been extensively studied: BIBR 1532 (2-((E)-3-naphtalen-2-yl-but-2-enolylamino)-benzoic acid) and Costunolide. The beneficial effect of caloric restriction, especially GR, on life span extension and cancer prevention and treatment has been very well documented. However, cell metabolic changes during this stress, especially on the enzymes activities, are not completely understood [3].
In the present study, we investigated the effects of BIBR 1532 on cell proliferation, mitochondrial metabolism, and apoptosis in MDA-MB 231 and MCF-7 cells under restricted glucose conditions. Furthermore, the role of GR on the telomerase activity and cell division rate was assessed for extended periods.

Our in vitro study showed that cell glucose deprivation dramatically decreases the telomerase mRNA expression and activity and cell proliferation. The important role of 


\section{MDA-MB 231 cell line}

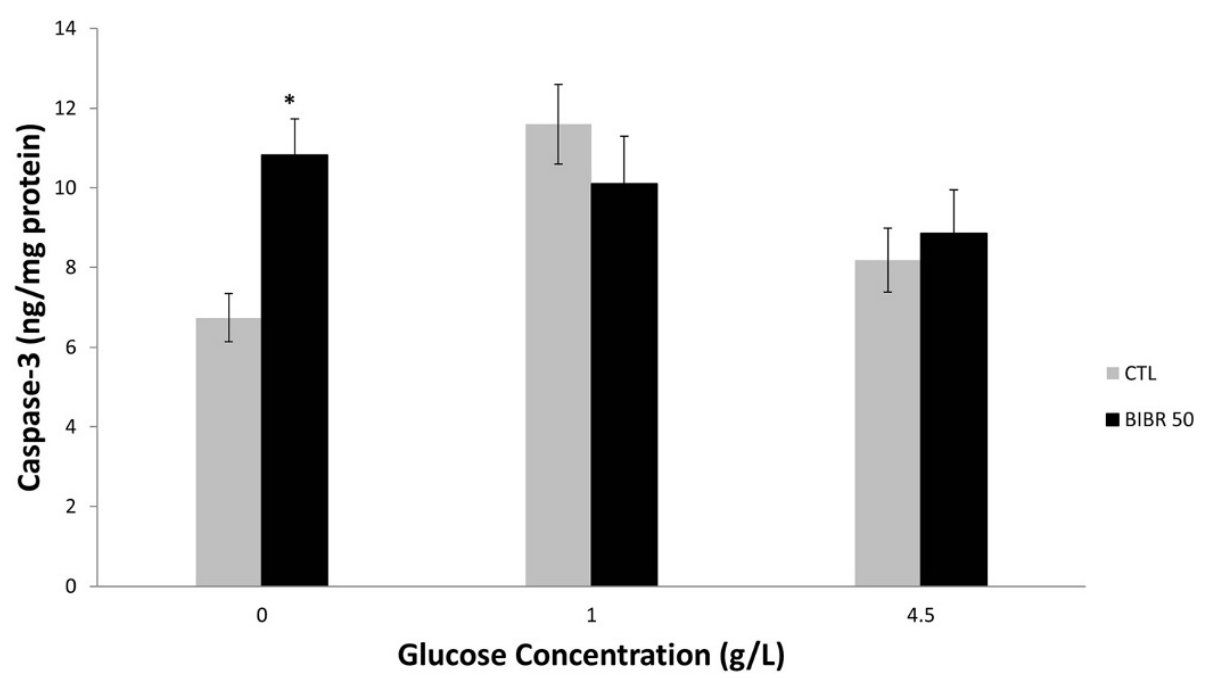

Figure 7 Effect of high BIBR 1532 concentration on cell apoptosis. MDA-MB 231 cells grown at different glucose concentrations were seeded in 6-well plates at a density of $2 \times 10^{5}$ cells per well. After adherence, the cells were treated with $50 \mu \mathrm{M}$ BIBR 1532 for 48 hours. After treatment, the culture media was discarded, and the cells were harvested and lysed as mentioned in materials and methods to further quantify the caspase-3 level via ELISA and measure the protein concentration. Bars represent values from at least three independent experiments $\left({ }^{*} \mathrm{p}<0.05\right)$.

telomerase in cancer cell immortalization agrees with previous studies that reported a correlation between caloric restriction and cancer prevention and treatment. The cells incubated in $0 \mathrm{~g} / \mathrm{l}$ of glucose were actually exposed to $0.65 \mathrm{~g} / \mathrm{l}$ from FBS, which perfectly matches the physiological glycaemia in fasting state, whereas $1 \mathrm{~g} / \mathrm{l}$ glucose mimics a postprandial state and $4.5 \mathrm{~g} / \mathrm{l}$ mimics non-controlled glycaemia in diabetic patients or constant high glucose consumption. The increased telomerase activity in the presence of high glucose concentrations could at least partly explain the association between diabetes and cancer predisposition [31,32].

Despite the similar hTERT expression in cells grown in 1 and $0 \mathrm{~g} / \mathrm{l}$ of glucose, a complementary experiment involving the cell count showed different results. In fact, cells grown in media containing 4.5 and $1 \mathrm{~g} / \mathrm{l}$ of glucose were relatively similar, with minor significant differences in the cell number compared to cells grown in $0 \mathrm{~g} / \mathrm{l}$ of glucose.

To confirm the role of telomerase on mitochondrial metabolism, a WST-1 assay was performed on a cell line negative for human telomerase (Saos-2). The same pattern in the mitochondrial metabolism that was observed for MDA-MB 231 and MCF-7 cells was found in the osteosarcoma cell line Saos-2. The same experiments were extended to investigate the effect of BIBR 1532 under restricted glucose conditions. We began by examining the effect of this inhibitor on cell proliferation. The MDA-MB 231 cell number reduced to almost zero when the cells were treated with BIBR 1532. These results could be explained by an increased vulnerability of telomerase to its inhibitor in response to GR.

Mitochondria are important organelles specified in energy production and cellular calcium homeostasis, and the capacity to release apoptotic proteins (members of the Bcl-2 family) is of important consideration [33]. Moreover, mitochondria are considered to be a major intracellular source of ROS. Succinate dehydrogenase $(\mathrm{SDH})$, also known as quinone oxidoreductase, is a key regulator of metabolism and aerobic energy production. It couples the oxidation of succinate in the citric acid cycle to the reduction of ubiquinone in the electron transport chain, allowing cells to rely more on mitochondrial oxidative phosphorylation (OXPHOS) than aerobic glycolysis. Thus, this enzyme could reflect the activity of the mitochondrial respiratory chain [34]. Cell oxidative stress is produced with increased OXPHOS. These ROS have been implicated as second messengers in multiple signaling pathways, especially in apoptosis, as indicated by many reports [35]. We suggest that cells become more dependent on the Warburg effect than on OXPHOS after reducing the dehydrogenase activity via BIBR 1532 in 1 and $4.5 \mathrm{~g} / \mathrm{L}$ of glucose. Aerobic glycolysis allows cells to rapidly multiply and contributes to ROS detoxification because carbons are diverted into the pentose phosphate pathway (PPP). This mechanism helps cancer cells survive under oxidative stress [36].

In MDA-MB 231, a high BIBR 1532 concentration did not stimulate apoptosis, as assessed by caspase- 3 measurement, except for cells grown in $0 \mathrm{~g} / \mathrm{l}$ of glucose 
a MDA-MB 231 cell line

$0 \mathrm{~g} / \mathrm{L}$ glucose (Control)

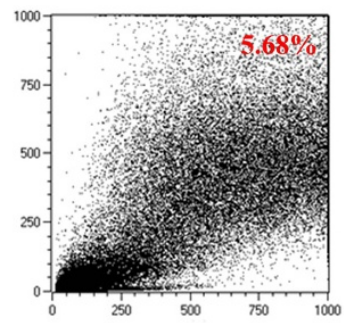

$0 \mathrm{~g} / \mathrm{L}$ glucose (BIBR 50)

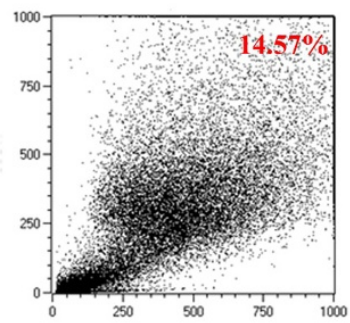

$1 \mathrm{~g} / \mathrm{L}$ glucose (Control)

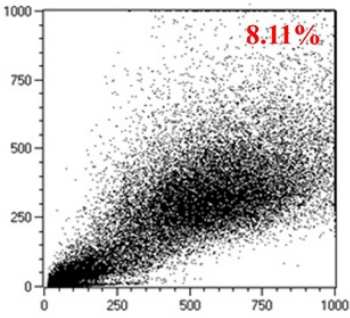

$1 \mathrm{~g} / \mathrm{L}$ glucose (BIBR 50)

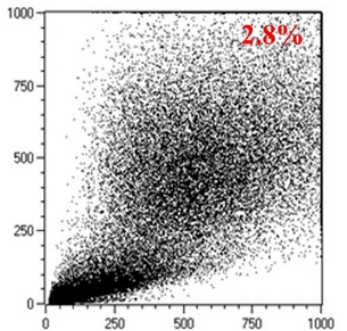

$4.5 \mathrm{~g} / \mathrm{L}$ glucose (Control)

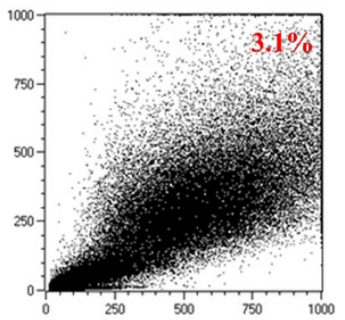

$4.5 \mathrm{~g} / \mathrm{L}$ glucose (BIBR 50)

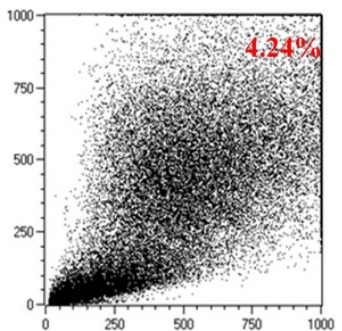

b $\mathrm{MCF}-7$ cell line

$0 \mathrm{~g} / \mathrm{L}$ glucose (Control)

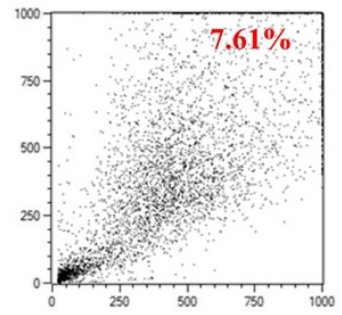

$0 \mathrm{~g} / \mathrm{L}$ glucose (BIBR 50)

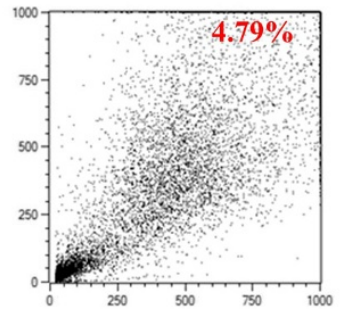

$1 \mathrm{~g} / \mathrm{L}$ glucose (Control)

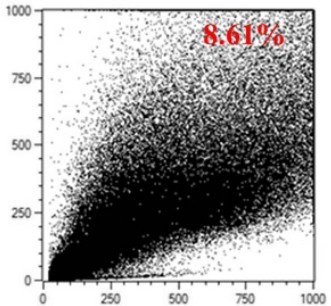

$1 \mathrm{~g} / \mathrm{L}$ glucose (BIBR 50)

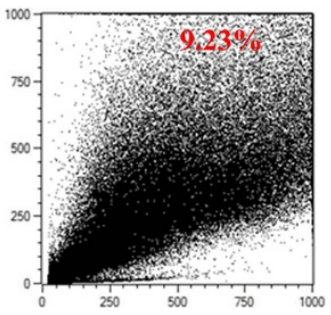

$4.5 \mathrm{~g} / \mathrm{L}$ glucose (Control)

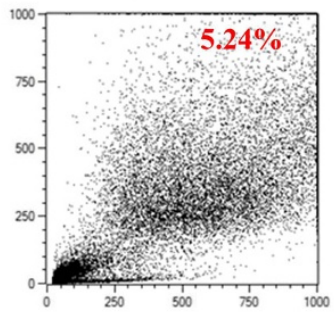

$4.5 \mathrm{~g} / \mathrm{L}$ glucose (BIBR 50)

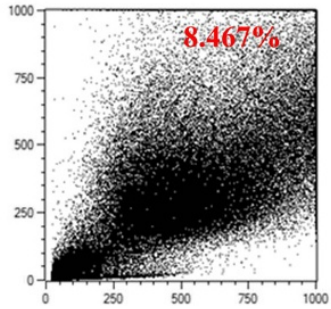

Figure 8 FACS analysis of BIBR 1532-treated a. MDA-MB 231 and b. MCF-7 cells. Cells were treated with $50 \mu M$ BIBR 1532 for 48 h and subsequently stained for Annexin-V and PI. The results represent three experiments.

independently of SDH activity modulation. This result could be explained by the extra-telomeric function of telomerase, i.e. its anti-apoptotic role [37]. The remaining telomerase activity $(\sim 20 \%)$ could sustain the proliferative capacity of cells grown in low glucose. The additive reduction activity of telomerase enhanced by BIBR 1532 treatment rendered cells more susceptible to apoptotic signals triggered by this inhibitor and was sufficient to induce caspase-3 expression in MDA-MB 231 cells. The absence of apoptosis mediated by the telomerase inhibition in MCF-7 cells is likely due to the up-regulation of hTERT by the estrogen receptor [38]. Further studies 
Table 1 Percentage of apoptotic MDA-MB 231 cells treated with high BIBR 1532 concentration cells

\begin{tabular}{ccc}
\hline Cell line & Treatment & \% of apoptotic cells \\
\hline MDA $0 \mathrm{~g} / \mathrm{L}$ & Control & $5.68 \%$ \\
MDA $0 \mathrm{~g} / \mathrm{L}$ & BIBR $1532(50 \mu \mathrm{M})$ & $14.57 \%$ \\
MDA $1 \mathrm{~g} / \mathrm{L}$ & Control & $8.11 \%$ \\
MDA $1 \mathrm{~g} / \mathrm{L}$ & BIBR 1532 $(50 \mu \mathrm{M})$ & $2.8 \%$ \\
MDA 4.5 g/L & Control & $3.1 \%$ \\
MDA 4.5 g/L & BIBR 1532 $(50 \mu \mathrm{M})$ & $4.24 \%$ \\
\hline
\end{tabular}

$(\mathrm{n}=3$, mean $\pm S D)$

should be conducted to examine the effect of BIBR 1532-mediated telomerase inhibition in the MCF-7 cell line.

Our results again suggest the importance of GR to inhibit telomerase action; an additive effect between GR and telomerase inhibition by BIBR 1532 is also evident in apoptosis initiation in the triple-negative cell line MDAMB 231.

\section{Conclusions}

This report demonstrated that the telomerase inhibitor BIBR 1532 exhibits an apoptotic effect via telomerase inhibition that is potentiated by restricted glucose conditions.

\section{Materials and methods}

\section{Cell culture and glucose restriction}

The established human triple-negative breast carcinoma cells (MDA-MB 231), human-estrogen positive breast carcinoma cells (MCF-7) and human negative telomerase osteosarcoma cells (saos-2) were purchased from ATCC (American Type Culture Collection). All MDA-MB 231, MCF-7, and Saos-2 cells were cultured in DMEM (Dulbecco's modified eagle's media, Sigma-Aldrich) at different glucose concentrations (0, 1 and $4.5 \mathrm{~g} / \mathrm{l})$ and supplemented with 10\% FBS (fetal bovine serum, Sigma-Aldrich, Taufkirchen, Germany), 1\% Pen-Strep (penicillin-streptomycin, SigmaAldrich, Taufkirchen, Germany) and $2 \mathrm{mM}$ glutamine (Sigma-Aldrich, Taufkirchen, Germany) and maintained in a humidified atmosphere of $5 \% \mathrm{CO} 2$ at $37^{\circ} \mathrm{C}$. The cells were pre-incubated for five days in the appropriate

Table 2 Percentage of apoptotic MCF-7 cells treated with high BIBR 1532 concentration

\begin{tabular}{ccc}
\hline Cell line & Treatment & \% of apoptotic cells \\
\hline MCF-7 $0 \mathrm{~g} / \mathrm{L}$ & Control & $7.61 \%$ \\
MCF-7 $0 \mathrm{~g} / \mathrm{L}$ & BIBR $1532(50 \mu \mathrm{M})$ & $4.79 \%$ \\
MCF-7 $1 \mathrm{~g} / \mathrm{L}$ & Control & $8.61 \%$ \\
MCF-7 $1 \mathrm{~g} / \mathrm{L}$ & BIBR $1532(50 \mu \mathrm{M})$ & $9.23 \%$ \\
MCF-7 $4.5 \mathrm{~g} / \mathrm{L}$ & Control & $5.24 \%$ \\
MCF-7 $4.5 \mathrm{~g} / \mathrm{L}$ & BIBR $1532(50 \mu \mathrm{M})$ & $8.46 \%$ \\
\hline
\end{tabular}

$(n=3$, mean $\pm S D)$. media, and treatment occurred when cells reached $80 \%$ confluence.

\section{Cell count}

MDA-MB 231 AND MCF-7 cells were seeded at very low densities in $25 \mathrm{~cm}^{2}$ flasks and grown in DMEM culture media containing 10\% FBS and 1\% Pen/Strep at different glucose concentrations with or without $2.5 \mu \mathrm{M}$ of BIBR 1532. The medium was replaced every two days, and fresh telomerase inhibitor was added each time. At the end of each week, the cells were split and counted at least three times using bromophenol blue and a hemocytometer. Figures $3 \mathrm{a}$ and $\mathrm{b}$ show the effect of GR and treatment with $2.5 \mu \mathrm{M}$ BIBR 1532 on MDA-MB 231 and MCF-7 cells by calculating the obtained cell number after each count on those seeded.

\section{Cell viability and mitochondrial metabolism assay}

The cell proliferation was evaluated using WST-1 (Takara Bio Inc, Ostu, Shiga, Japan), a tetrazoluim salt, cleaved into formazan by succinate-tetrazolium reductase, which exists only in the mitochondrial respiratory chain and is active only in viable cells. The production of formazan is directly related to the cell number due to the active mitochondrial metabolism and to its absorbance, which was measured using an ELISA reader at $450 \mathrm{~nm}$. In our study, cells grown in different glucose concentrations were seeded in 96-well plates at a density of $10^{4}$ cells per well and allowed to adhere for 24 hours, and the assay was performed following the manufacturer's instructions.

\section{Telomerase activity assay}

MDA-MB 231 and MCF-7 extracts, from 1.5 million cells for each condition, were prepared according to the manufacturer's protocol using a Quantitative Telomerase Detection Kit (Allied Biotech, Inc Vallego, California, USA). Briefly, the cell pellets were washed twice with cold PBS, and the cells were then lysed with an appropriate volume of the provided lysis buffer. After 30 minutes of incubation on ice, the suspension was centrifuged for $30 \mathrm{~min}$ at $4^{\circ} \mathrm{C}$ and $12000 \times \mathrm{g}$. The supernatant was then aliquoted to further assess the telomerase activity and protein concentration.

The telomerase activity was measured by Real-Time Polymerase Chain Reaction (PCR) (Applied Biosystem, USA), which is based on the ability of telomerase in the cell extracts to synthesize telomeric repeats onto an oligonucleotide substrate, and the resultant extended products are subsequently amplified by PCR. The generated PCR products were then visualized using the highly sensitive DNA fluorochrome SYBR Green. The PCR products were detected following the binding of SYBR Green dye to double-strand DNA. 


\section{Detection of hTERT and hTR gene expression}

Total RNA from MDA-MB 231 and MCF-7 cells was extracted using THE QIAamp RNA extraction Kit (Qiagen Inc., Valencia, CA, USA). Complementary DNA (cDNA) was synthesized from 0.1 to $2.5 \mu \mathrm{g}$ of total RNA in a $20-\mu \mathrm{l}$ reaction using the Omniscript Reverse Transcription Kit (Qiagen Inc., Valencia, CA, USA). The expression of hTERT and GAPDH was assessed using the multiplex hTERT/GADPH PCR technique and specific primers. The primers were defined as follows: hTERT: $5^{\prime}$-CGGAAG AGTGTCTGGAGCAA-3', 5'-GGATGAAGCGGAGTC TGGA-3'; hTR: 5'-GCGGAAGACAGTGGTGAACT-3', 5'-AGCTGGAGTAGTCGCTCTGC-3'; GAPDH (Glyceraldehyde 3-phosphate dehydrogenase): 5' -TGGGATGGA CTGTGGTCATGAG-3', 5' -ACTGGCGTCTTCACCAC CATGG3-', which was used as the internal control. PCR amplification was performed using Dream Taq Green PCR $2 \times$ Master Mix (Fermentas, USA), and the reactions were subjected to 40 PCR cycles (BioRad, Germany) of $94^{\circ} \mathrm{C}$ for 30 seconds, $60^{\circ} \mathrm{C}$ for 30 seconds, and $70^{\circ} \mathrm{C}$ for 30 seconds followed by 7 minutes of extension at $72^{\circ} \mathrm{C}$. The PCR products were separated via $1.2 \%$ agarose gel electrophoresis and visualized by ethidium bromide staining using the UVP BioDoc system (UVP, England).

\section{Protein quantification}

The protein concentration was measured with the Bradford method according to the manufacturer's recommendations using an acidic solution of Coomassie Blue G-250 dye, which is a reagent in the Bio-Rad Protein Assay, and BSA, which served as the standard. Serial dilutions of BSA at known concentrations were prepared. Five milliliters of Coomassie Blue solution ( $5 \times$ diluted) were added to the diluted proteins. The absorbance of the colored solution was measured with a spectrophotometer at $595 \mathrm{~nm}$.

\section{Caspase-3 apoptosis assay}

The caspase-3 level was determined using a caspase-3 (active) human ELISA Kit from Invitrogen. Briefly, MDAMB 23, MCF-7 and saos-2 cells were seeded in 6-well plates in DMEM at different levels of GR and treated with $50 \mu \mathrm{M}$ BIBR 1532. After 48 hours of treatment, the cells were collected in cold phosphate buffered saline $1 \times(\mathrm{PBS})$ and lysed with cell extraction buffer (10 mM Tris, pH 7.4, $100 \mathrm{mM} \mathrm{NaCl}, 1 \mathrm{mM}$ EDTA, $1 \mathrm{mM}$ EGTA, $1 \mathrm{mM} \mathrm{NaF}$, $20 \mathrm{mM} \mathrm{Na} \mathrm{P}_{2} \mathrm{O}_{7}, 2 \mathrm{mM} \mathrm{Na} \mathrm{VO}_{4}, 1 \%$ Triton X-100, 10\% glycerol, $0.1 \%$ SDS, $0.5 \%$ deoxycholate, $1 \mathrm{mM}$ PMSF and protease inhibitor cocktail). The cell extracts were then used to determine the concentration of caspase-3. The ELISA method was based on the fixation of cleaved caspase-3 at Asp 175/Ser 176 between two antibodies. This enzyme was detected after a detection antibody bound to the second antibody, followed by adding a substrate solution that was acted upon by the bound enzyme to produce color. The O.D. (optical density) of this colored product was measured at $450 \mathrm{~nm}$ with an ELISA Reader (Thermo Scientific, USA), and this O.D. is directly proportional to the concentration of human active caspase- 3 present in the sample.

\section{Annexin V-FITC apoptosis assay}

The FITC annexin V apoptosis detection kit (Abcam) was used following the manufacturer's instructions. MDAMB 231 and MCF-7 cells grown in different glucose concentrations were plated at a density of $2 \times 10^{5}$ cells/well on six-well plates. After $48 \mathrm{~h}$ of treatment with $50 \mu \mathrm{M}$ BIBR 1532, the cells were trypsinized and collected in ice cold PBS. The cells were washed twice with cold PBS and re-suspended in $500 \mu \mathrm{L}$ binding buffer containing $5 \mu \mathrm{L}$ Annexin V-FITC. The signals were detected using a FACScan flow cytometer (MACSquant, Germany) with excitation and emission settings of $452 \mathrm{~nm}$.

\section{TERT siRNA transfection}

MDA-MB 231 and MCF-7 cells were maintained in DMEM at different concentrations of glucose and plated in 96-well plates at a density of $2 \times 10^{4}$ cells per well. Prior to seeding, $5 \mu \mathrm{L}$ of specific siRNA, Hi-perfect (Qiagen) and serum-free media were added into each well and incubated for 10 minutes at ambient temperature. One hundred microliters of cell suspension were added to each well to initiate a treatment of $72 \mathrm{~h}$. Two siRNAs were used in this assay; the first was TERT3, which targets the mRNA of the sub-catalytic unit of telomerase and the second was Death, which targets expressed human genes that are indispensable for cell survival. This siRNA was used as a positive control because it induces cell death that was visible by light Microscopy. The siRNA sequences were designed with the RNAi Human/Mouse Starter Kit (Qiagen Inc., Valencia, CA, USA). For hTERT, the siRNA sense sequence was 5' -GGAGCAAGUUGCAAAGCAUTT-3' and the anti-sense was $5^{\prime}$-AUGCUUUGCAACUUGCU CCAG-3', the target sequence was $5^{\prime}$-CTGGAGCAA GTTGCAAAGCAT-3'. Transfection monitoring was assured by the cell death control siRNA, which is a blend of siRNAs that target human genes essential for cell survival.

\section{Statistical analysis}

The statistical analysis was performed with $t$-test using the online statistical software Graph-Pad Quickcalcs (http://www.graphpad.com/quickcalcs/ttest1.cfm).

\section{Ethical committee}

This project was approved by the Ethical Committee of the Faculty of Medicine of Saint-Joseph University, number $53 / 2012$. 


\section{Abbreviations}

CR: Caloric restriction; GR: Glucose restriction; hTERT: Human telomerase reverse transcriptase; hTR: Human template RNA; ROS: Reactive oxygen species; SDH: Succinate dehydrogenase; ER: Estrogen receptor; PR: Progesterone receptor.

\section{Competing interests}

We state here that none of our authors has financial or other competing interests that might be construed as influencing the results or interpretation of our study.

\section{Authors' contributions}

LW carried out the cell culture, the telomerase activity measurement, and the mitochondrial metabolism experiments and drafted the paper. NA, IR and RS contributed to the design of the study, drafted the paper and contributed to the discussion. RS performed the ELISAs experiments. CK performed the flow cytometry experiments. GH proposed the original idea of this study, designed the experiments and drafted the paper. All authors read and approved the final manuscript.

\section{Acknowledgements}

We are very thankful to Dr. Rabih Talhouk at the American University in Beirut for providing the MDA-MB 231 and MCF-7 breast cancer cell lines.

\section{Author details}

${ }^{1}$ Cancer and Metabolism Laboratory, Faculty of Medicine, Campus of Medical Sciences, Saint-Joseph University, Damascus Road, P.O.Box 11-5076, Riad el Solh, Beirut 1107 2180, Lebanon. Regenerative Medicine Laboratory, Faculty of Medicine, Saint-Joseph University, Beirut, Lebanon. ${ }^{3}$ Department of Infectious Diseases, the University of Texas M. D. Anderson Cancer Center, Houston, TX, USA. ${ }^{4}$ Surgery Department, Faculty of Medicine, Saint-Joseph University and Hotel-Dieu de France, Beirut, Lebanon.

\section{Received: 27 December 2013 Accepted: 5 June 2014}

Published: 4 July 2014

\section{References}

1. Osborne TB, Mendel LB, Ferry EL: The effect of retardation of growth upon the breeding and duration of life of rats. Science 1917, 45:294-295.

2. Martin B, Golden E, Egan JM, Mattson MP, Maudsley S: Reduced energy intake: the secret to a long and healthy life? IBS J Sci 2007, 2:35-39.

3. Longo VD, Fontana $\mathrm{L}$ : Calorie restriction and cancer prevention: metabolic and molecular mechanisms. Trends Pharmacol Sci 2010, 31:89-98.

4. Colman RJ, Anderson RM, Johnson SC, Kastman EK, Kosmatka KJ, Beasley TM, Allison DB, Cruzen C, Simmons HA, Kemnitz JW, Weindruch R: Caloric restriction delays disease onset and mortality in rhesus monkeys. Science 2009, 325:201-204

5. Fontana L, Klein S: Aging, adiposity, and calorie restriction. JAMA J Am Med Assoc 2007, 297:986-994

6. Hanahan D, Weinberg RA: Hallmarks of cancer: the next generation. Cell 2011, 144:646-674.

7. Kolonel LN, Altshuler D, Henderson BE: The multiethnic cohort study: exploring genes, lifestyle and cancer risk. Nat Rev Cancer 2004, 4:519-527.

8. Baade PD, Youlden DR, Krnjacki LJ: International epidemiology of prostate cancer: geographical distribution and secular trends. Mol Nutr Food Res 2009, 53:171-184

9. Safdie FM, Dorff T, Quinn D, Fontana L, Wei M, Lee C, Cohen P, Longo VD: Fasting and cancer treatment in humans: a case series report. Aging 2009, 1:988-1007.

10. Kim NW, Piatyszek MA, Prowse KR, Harley CB, West MD, Ho PL, Coviello GM, Wright WE, Weinrich SL, Shay JW: Specific association of human telomerase activity with immortal cells and cancer. Science 1994 266:2011-2015.

11. Janknecht R: On the road to immortality: hTERT upregulation in cancer cells. FEBS Lett 2004, 564:9-13.
12. Autexier $C$, Lue NF: The structure and function of telomerase reverse transcriptase. Annu Rev Biochem 2006, 75:493-517.

13. Shay JW, Wright WE: Senescence and immortalization: role of telomeres and telomerase. Carcinogenesis 2005, 26:867-874.

14. Hursting SD, Lavigne JA, Berrigan D, Perkins SN, Barrett JC: Calorie restriction, aging, and cancer prevention: mechanisms of action and applicability to humans. Annu Rev Med 2003, 54:131-152.

15. Grizzi F, Di leva A, Russo C, Frezza EE, Cobos E, Muzzio PC, Chiriva-Internati $\mathrm{M}$ : Cancer initiation and progression: an unsimplifiable complexity. Theor Biol Med Model 2006, 3:37.

16. DeBerardinis RJ, Lum JJ, Hatzivassiliou G, Thompson CB: The biology of cancer: metabolic reprogramming fuels cell growth and proliferation. Cell Metab 2008, 7:11-20.

17. Hsu PP, Sabatini DM: Cancer cell metabolism: warburg and beyond. Cell 2008, 134:703-707.

18. Warburg O: On respiratory impairment in cancer cells. Science 1956, 124:269-270.

19. Hammerman PS, Fox CJ, Thompson CB: Beginnings of a signal-transduction pathway for bioenergetic control of cell survival. Trends Biochem Sci 2004 29:586-592.

20. Kyo S, Takakura M, Taira T, Kanaya T, Itoh H, Yutsudo M, Ariga H, Inoue M: Sp1 cooperates with c-Myc to activate transcription of the human telomerase reverse transcriptase gene (hTERT). Nucleic Acids Res 2000, 28:669-677.

21. Klement RJ, Kämmerer $\mathrm{U}$ : Is there a role for carbohydrate restriction in the treatment and prevention of cancer? Nutr Metab 2011, 8:75.

22. Jiang $W$, Zhu Z, Thompson HJ: Dietary energy restriction modulates the activity of AMP-activated protein kinase, Akt, and mammalian target of rapamycin in mammary carcinomas, mammary gland, and liver. Cancer Res 2008, 68:5492-5499.

23. Pollak M: Insulin and insulin-like growth factor signalling in neoplasia. Nat Rev Cancer 2008, 8:915-928.

24. Seyfried TN, Shelton LM: Cancer as a metabolic disease. Nutr Metab 2010, 7:7.

25. Li Y, Liu L, Tollefsbol TO: Glucose restriction can extend normal cell lifespan and impair precancerous cell growth through epigenetic contro of hTERT and p16 expression. FASEB J Off Publ Fed Am Soc Exp Biol 2010, 24:1442-1453.

26. Pascolo E, Wenz C, Lingner J, Hauel N, Priepke H, Kauffmann I, Garin-Chesa P, Rettig WJ, Damm K, Schnapp A: Mechanism of human telomerase inhibition by BIBR1532, a synthetic, non-nucleosidic drug candidate. J Biol Chem 2002, 277:15566-15572.

27. Janjic $D$, Wollheim CB: Islet cell metabolism is reflected by the MTT (tetrazolium) colorimetric assay. Diabetologia 1992, 35:482-485.

28. Berridge MV, Tan AS: Characterization of the cellular reduction of 3-(4,5-dimethylthiazol-2-yl)-2,5-diphenyltetrazolium bromide (MTT): subcellular localization, substrate dependence, and involvement of mitochondrial electron transport in MTT reduction. Arch Biochem Biophys 1993, 303:474-482.

29. Pantic M, Zimmermann S, El Daly H, Opitz OG, Popp S, Boukamp P, Martens UM: Telomere dysfunction and loss of p53 cooperate in defective mitotic segregation of chromosomes in cancer cells. Oncogene 2006 25:4413-4420.

30. Pantic M, Zimmermann S, Waller CF, Martens UM: The level of telomere dysfunction determines the efficacy of telomerase-based therapeutics in a lung cancer cell line. Int J Oncol 2005, 26:1227-1232.

31. Nicolucci A: Epidemiological aspects of neoplasms in diabetes. Acta Diabetol 2010, 47:87-95.

32. Sauer LA, Dauchy RT: Stimulation of tumor growth in adult rats in vivo during acute streptozotocin-induced diabetes. Cancer Res 1987, 47:1756-1761

33. Brookes PS: Mitochondrial proton leak and superoxide generation: an hypothesis. Biochem Soc Trans 1998, 26:S331.

34. Oyedotun KS, Lemire BD: The quaternary structure of the Saccharomyces cerevisiae succinate dehydrogenase. Homology modeling, cofactor docking, and molecular dynamics simulation studies. J Biol Chem 2004 279:9424-9431.

35. Apel $\mathrm{K}$, Hirt $\mathrm{H}$ : Reactive oxygen species: metabolism, oxidative stress, and signal transduction. Annu Rev Plant Biol 2004, 55:373-399.

36. Anastasiou D, Poulogiannis G, Asara JM, Boxer MB, Jiang J, Shen M, Bellinger G, Sasaki AT, Locasale JW, Auld DS, Thomas CJ, Vander 
Heiden MG, Cantley LC: Inhibition of pyruvate kinase M2 by reactive oxygen species contributes to cellular antioxidant responses. Science 2011, 334:1278-1283.

37. Shay JW, Wright WE: Telomerase therapeutics for cancer: challenges and new directions. Nat Rev Drug Discov 2006, 5:577-584.

38. Zhou C, Steplowski TA, Dickens HK, Malloy KM, Gehrig PA, Boggess JF, Bae-Jump VL: Estrogen induction of telomerase activity through regulation of the mitogen-activated protein kinase (MAPK) dependent pathway in human endometrial cancer cells. PLoS One 2013, 8:e55730.

doi:10.1186/1475-2867-14-60

Cite this article as: Wardi et al:: Glucose restriction decreases telomerase activity and enhances its inhibitor response on breast cancer cells: possible extra-telomerase role of BIBR 1532. Cancer Cell International 2014 14:60

\section{Submit your next manuscript to BioMed Central and take full advantage of:}

- Convenient online submission

- Thorough peer review

- No space constraints or color figure charges

- Immediate publication on acceptance

- Inclusion in PubMed, CAS, Scopus and Google Scholar

- Research which is freely available for redistribution 